\title{
Presenting the Era (Masa)
}

\section{Aji Dedi Mulawarman}

University of Brawijaya, J1. MT. Haryono, Malang, East Java, Indonesia

ajidedim@ub.ac.id

\section{ARTICLE INFO}

Article history

Received 7 June 2020

Revised 18 August 2020

Accepted 25 September 2020

Keywords

Era

Al-Ashr

Presence

Consciousness

Philosophy of time
ABSTRACT

This article aims to present a concept of era (masa) based on the Qur'anic idea of Al-Ashr. At the first presence, era, whether at historical level, or transcending it, has never escape holiness, as time and space where sacred moral act is always present. At the second presence, era is, in essence, holiness as a reality of being, reality of existence, and presence, where the entire range of the past, present and future is no longer important, even lost, but is a reality that is present in the era without era. At the third presence, holiness, on the other hand, must be historical for the task of the public in the name of love for God, which is part of the deepest consciousness of every human being and human relations where the past, present and future move historically in space and time. At the fourth presence, the real man is thus a man who always purifies his soul without pause in the historical space of time, even beyond it. At the fifth presence, the act of "so be it" (kun fayakun) of God exists, time exists throughout the span of time without any preconditions or constructions based on His commandments (namely Ibn Arabi Bipolar Triplisity).

This is an open access article under the CC-BY-SA license

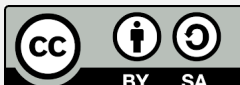

\section{Introduction}

By the Era, indeed mankind is in loss. Except for those who have believed and done righteous deeds and advised each other to truth and advised each other in patience (QS. Al-Ashr:1-3)

The sign of piety in a man is the loss of horizon in himself (Muhammad Iqbal)

This writing about "the era", masa, where time and space are present, was initiated when I was oftenly disturbed by the inconsistency of reality that was never fair and honest. This paper is also a continuation of the discourse results from my time in various forums since publishing the book "2024 Hijrah untuk Negeri" in mid 2016. The book review has spread to various cities in Indonesia until 2019. Since then, curiosity about the concept of the era has increased.

The first important trigger was when I was at the Sharah (interpretation) of HOS Tjokroaminoto Thought History Discussion forum which was held by the Peneleh 
foundation for activists on November 15-17, 2019 in Malang. For three days the event, which was attended by 7 activists, was like an awakening the discourse of HOS Tjokroaminoto's past struggles. For most, the history of his thoughts is only a part of historical discourse. It is rarely examined in depth as to how the historical power of his thoughts can trigger communal awareness of many prominent figures of Indonesian leaders that gave birth to the nation's independence until what can be seen in Indonesia today. I realized that it was not only HOS Tjokroaminoto who was the trigger for consciousness as there were many figures in his time, such as KH. Wahab Chasbullah, KH. Ahmad Dahlan, and Soewardi Soerjaningrat (Ki Hadjar Dewantara).

The second important trigger was when I reopened the letters of Mandor Klungsu or Djoko Pring, as he called himself, known as RMP Sosrokartono, that were written around 1931, where he was invited by the Sultan of Langkat [1]. The letters were written in Javanese and sent to his friends at the Darus Salam hermitage, Bandung, from 12 May to 12 November. His letters do not only express his experiences of physical travel, but also describe profound spiritual experiences in the middle of practicing only eating chilies every day. Important repetition sentences appear in many of these letters with some variations or differences but with the same meaning, such as: "Ngawula dhateng kawulaning Gusti, lan memayu ayuning urip, tanpa pamrih, tanpa ajrih; jejeg mantep, mawi pasrah" (to obey to God, to beautify life, without interest, without fear, determined and surrender to God)

For me, HOS Tjokroaminoto and RMP Sosrokartono were two important figures behind Soekarno's strength during his studies in Surabaya and Bandung. I understand that Soekarno also interacted with many figures and situations, in abundant space and time, which led to the apex of Indonesian history on August 17, 1945, when independence of nation was proclaimed and this country entered a new era with a new name: Indonesia. Even so, it is rare for these two figures to be seen in historical lines as important doors for major changes in Soekarno's later self. In Surabaya, for Soekarno learning was through the HOS Tjokroaminoto where he became acquainted with Islam, nationalism, patriotism, books, organizations, partisanship, the spirit of struggle and the importance of being a leader to bring the country to its authenticity standing on its own feet, Zelfbestuur. In Bandung, Soekarno was learning about caring behavior, spirituality of the soul, and inner politeness. Zelfbestuur transcends space-time with the Sincere Teacher, RMP Sosrokartono.

It was from this interaction that I began to re-examine whether the chronology of history is not only a line of records of dates and years, but also contains inner strength that shot beyond its era. After the Discussion Forum of HOS Tjokroaminoto History of Thought, my inner turmoil escalated to its peak on Sunday, 27 Rabiul Awwal $1441 \mathrm{H}$ or 24 November 2019. I started tracing the concept of "era" since that very dawn, until the writing was finished on Sunday 4 Rabiul Akhir 1441 H or 1 December 2019.

\section{Method}

This section delineates the search of the meaning of "Era". My confusion was started with the search for the meaning of the word "era" (masa). Based on the National Indonesian Dictionary", the word "masa" has many meanings, depending on its nature. "Masa" as a root word can have a meaning both as a noun and an adverb (a word that

\footnotetext{
${ }^{1}$ https://kbbi.web.id/masa was accessed on 24 November 2019. Similar meaning can be found in https://kbbi.kemdikbud.go.id/entri/masa
} 
describes a verb, adjective, other adverb, or sentence). "Masa" also has the meaning of a classic noun, namely:

"... to mark the word labeled it is used in a variety of Classical Malay literature," as well as the noun "archeology". "Masa", as the first noun can mean: "(1) time; when; moment; (2) a long period of time when an important event occurs; or (3) a certain period of time with a beginning and a limit. "Masa": "as a classic noun, namely "termasa" which means excursion". "Masa": "as another noun, namely archeology, means the unit of measurement for gold and silver (in the abbreviated inscription ma, $1 \mathrm{ma}=2,412 \mathrm{~g})$ ". Meanwhile, as an adverb "Masa" means "a word to express distrust and its rhetorical nature, for example: how could he lie?". The word "masa": "also means signs, namely signs that something will happen, which is a sign or an address for an event to occur, or movement". There is an exception when the word "masa" is juxtaposed with the word stupid, namely: "indifferent as an adjective (a word that describes a noun or pronoun), and as a verb (verb)". Indifference as an adjective: "means the affective word to express displeasure; up to you; however you like. To be ignorant as a verb means not to care about anything; not paying attention at all; indifferent".

Not wanting to stop there, the search moved in another direction: Al Qur'an. The "era" or "masa" or ashr according to the Al-Qur'an is specifically written in Surah number 103, which I quoted at the beginning of this article, namely the Surah Al-Ashr: "By the era. Truly humans are at a disadvantage. Except (four things, namely) being faithful and doing good deeds, and always testifying about the Haq and testifying in patience". Ashr, by some experts, is recognized as "period", namely the period in which something goes through life, from the beginning to the end, where at the end, there is a period that has a meaning other than ashr, namely the time of death[2].

Uniquely, as the mystery of numbers from the phenomenal book of Annemarie Schimmel [3] published by Oxford ${ }^{2}$ which also continues the tradition of the great figure Ulf Diederichs from Germany, numerical mathematics in the Qur'an Surah Al Ashr is not only profane, but also has deep spiritual meaning. The sum of the number of Surah AlAshr in the Quran is $4(1+0+3)$. The number 4 in many traditions does have the meaning of makrifat, non-material numbers, as well as the meaning of earth. The number 4 according to Javanese tradition can mean Papat or Sekawan which means Catur (creativity, intelligence) and Kerta (victory). The number 4 in the Chinese tradition is a number to avoid, because it means death, especially material death, I think.

Numbers for Islam do have an inescapable congruence to the Holy, that is why the tradition of mathematics has never been separated from the Reality of Allah, Holiness itself. The algorithm, which first appeared through the ideas of numbers and mathematics from Al-Khawarizmi, is a reflection of the search for God and Holiness itself, although in the name of secularization and modernity atheism, became the basis for the most recent

\footnotetext{
${ }^{2}$ This book explains the magical, spiritual, and religious beliefs of numbers in many of the traditions of the world's major religions, such as Islam, Christianity, Hinduism, Buddhism, Judaism, Zoroaster, and others. Including, one of which is the spiritual nature of all numbers, including the number 4 which is discussed in depth.
} 
technological science. The Industrial Revolution 4.0 broke away further from holiness and Single Reality [4].

Numbers and mathematics for the West may be represented as, David Hilbert ${ }^{3}$ said during his lecture on "The Foundations of Mathematics" in Hamburg, a science that does not need God: "Already at this time I would like to assert what the final outcome will be: mathematics is a presuppositionless science. To found it, I don't need God..." [5,6]. The rebuttal from Einstein's colleague, Kurt Godel, turned out to be even more palpable, saying that God never cease to exist and moreover always exists in all realities including numbers and mathematics. Godel's comments seem to be an expression of his approval of Galileo Galilei's logic: "Mathematics is the language in which God has written the universe".

It turns out that the discourse of numbers, mathematics, and God ${ }^{4}$ never halts, even though the domination of discussion centers on conception that numbers and mathematics are realities as they are, while God has never been present in them. I think the reduction of the Holy Reality of all numeral (mathematics) niches starts from the anthropocentricity of the European Renaissance as emphasized by Isaac Newton through his magnum opus "The Mathematical Principles of Natural Philosophy". Many responses to Newton's writings understand mathematics as a secular representation, in contrast to his understanding of the universe in which God wills. Newton's writings then triggered and became part of the early scientific discourses of the release of God and holiness from science, including numbers, mathematics, and physics, as in the Cartesian tradition [7]. ${ }^{5}$

The fusion of numbers, mathematics, and physics in understanding reality has become an increasingly popular discourse, after Einstein through his general theory of relativity stated that there is a singularity of reality, where space and time are not linear as imagined by Newton. To his accordance, space and time (where the era or masa is present and exists) have curvature towards the immeasurable so that space and time lose their meaning. The discourse still continues today such as the secret of the sky with many stars in the middle of millions of galaxies that are expanding rapidly, as well as various historical possibilities and the future of the universe in the eyes of various theories such as the Black Hole, Multiverse, Big Bang, Steady State, Inflation Theory, Theory of Everything, MTheory, and many others, including other parallel universes that may be connected (or could collide with ours). For cosmologists, the age of our universe (from the findings of

3 David Hilbert is one of the mathematical figures from Germany who greatly influenced the world of mathematical science in the world (1862-1943). Hilbert can be called the Father of Modern Mathematics because according to some colleagues and mathematicians he has launched what is known as Metamathematics or Beyond Mathematics (see page 63).

${ }^{4}$ Discourses on this subject including Godel's arguments can be seen for example in Lawrence, S. and M, McCartney (eds.).

5 See final comment of Strong (1952) after investigating many experts regarding Newton's contradictory ideas and thoughts about Mathematics, Nature and God: "There is no indication that Newton was ever troubled in his mind about the compatibility of his scientific theory with the attributes of a Christian Deity. He assumed that the world was God's world. Whatever properties and relations that the world was discovered to have could not be inconsistent with God. It is highly doubtful that Newton was aware that in attributing space and time to the sensorium of God, he had radically departed from traditional Christian cosmology. His theological interpretation nevertheless retains the pathos of that cosmology in affirming a Providential Deity, but a Deity whose work is so well constituted that it can continue for ages without need of reform. A scientist needs no knowledge of God to know the mechanism of things, but it would nonetheless be impious to suppose that the world could exist in its order without supervision of an intelligent Agent." 
the satellite both WMAP, PLANK, and awaits other findings) is 13.7 billion years old, like the mathematical calculation of the Qur'an, which numerologists claim, has presented 1400 years of evidence [8].

Both Western rational calculation (Western cosmology discourses and the Theory of Universe) and Quran normative calculation are correct, even if, it could be that there is one pixel missing or it could be 1 ayah less, and it could just be that the calculation of universe age will shift later. Such are the cosmology and the latest theory of the universe, fossil observation and who knows what else the survivors of this universe imagined, all of which contribute to my theoretical discourse. In fact, later there will be modeling and theoretical findings that are still not final, such as the big crunch, big freeze, towards the end of the world, or some say there will be a time where we will return to the beginning of the universe. This reminds us of the Qur'anic story that is very similar to the metaphor of bouraq as the vehicle of the Prophet Muhammad PBUH, when he crossed the seven heavens in Isra 'Mi'raj.

Numbers and mathematics for Muslim intellectuals have long been considered as unity itself: "... as the gateway leading from the sensible to the intelligible world, the ladder between the world of change and the heaven of archetypes ..." [9]. In fact, a group of scientists and philosophers who played an important role in Islamic civilization during the Abbasid era, Basrah, Iraq, Ikhwan Al-Shafa (Holy Brotherhood). Their peak work, magnum opus, Rasa'il Ikhwan Al-Shafa which consists of 52 treatises, begins with 14 treatises on mathematics affirming the belief that all the nature of creation is always in accordance with the nature of numbers: "This is our Brotherhood school of thought" [10]. The Al-Shafa Brotherhood also has special attention to the number 4 as: "... an honor that goes beyond the realm of pure mathematics"[10].

When we return to the meaning of $A s h r$, it is possible that first and foremost importance is faith. Faith refers to the one, Haq, Allah, Tawheed, represented by the letter Alif which also means number 1 . The word Allah according to its letter formation comes from 4 Arabic letters, namely Alif, Lam, Lam, and $H a^{\prime}$ (as the word Muhammad is formed from 4 letters, Meem, Ha', Meem, Dal). Alif and number 1 in the word Allah represent the beginning, followed by the role of humans as monotheistic humans (represented by number 1) entering in space and time, the past, present, and future, through the representation of the lam-lam in tashdid, representing infinite universe, which ends in ha' which represents emptiness, or zero (0), (or in Javanese language is termed ad suwung).

This realization bears important meaning, which is that after believing, we are required to empty ourselves from various interests, to reach the peak of faith (kemakrifatan), so that doing good deeds, testifying about the truth and patience become true, not only in diction, pretense, language, trite or whatever kind of action. Doing good deeds must spring from true intention, present in space and time, with absolute sincerity, without reservation.

An important satire regarding space and time can be seen from one of the episodes of the Sosrokartono RMP trip in North Sumatra (around Medan, Langkat, Aceh) at the invitation of the Sultan of Langkat. Historical travel in space and time for him is not limited only to situations and matters of traveling across distances and places, nor only into situations of eating and thinking about the world; for such practice would cause human "to loosen up or reverse unseen intentions as well as to divert the purpose of the journey itself": 
"Ingkang nyarengi lampah kula ing pundi-pundi inggih Tengku Ibrahim punika. Sanged bingahipun, jalaran saged sumerep jajahan lan wewah kawruh lan tepangan. Tiyangipun sae lan lurus manahipun, inggih kaleresan sanget. Kuciwanipun puniko kemawon: ing pundi-pundi anggalih wanci, anggalih padharan. Tegesipun, kedah sering ngaso lan dhahar. Tumrap ing ulun, perkawis kalih punika kalebet awisan praja. Tiyang mlampah piniko sangunipun lan gembolanipun namung barang satunggal, inngih puniko maksudipun. Barang Sanesipun kengung dipun wastani ugi ngreribeti lan ngawrati lampah. Kenging dipun wastani ugi: ngendhoni niyat utawi nginger ancas lan tujuaning lampah." [1]

Accompanying my trip wherever I went, was Tengku Ibrahim. I am very happy because I can explore and increase knowledge and acquaintances. He is also kind and upright. Unfortunately, one always thinks about time spent, and thinks about one's stomach. This means that you must often rest and eat. For me, these two things are actually basic prohibition. People should travel with their provisions and what is carried is only the one thing, namely the intention. Others will interfere and become burdensome for one's travel. They can relax the intention or change the real course and purpose of action.

Space-time is not quite like that, because in other space-time there are many situations in which many humans are deprived. Is the self never connected to many things, such as to the reality of society as a whole where they can no longer have happiness, fortune, let alone just having something to eat? Self-practice cannot be separated from the social reality wherever we are, because that is how we can understand inner purity leading to Divine holiness:

"Medal malih luh ing manah, kemutan para sesami ingkang saweg ginanjar nandhang susah lan sengsara. Boten kolu nedha, boten kolu ngombe, kemutan tiyang sakit. tiyang keluwen, semanten cacahipun. Ical sirna susah sayahipun pribadi. Anggagas, amandeng lan mantheng susahipun sesami. Luluh sakit lan susahipun pribadi wonten ing sagunging samodraning sakit lan sesaranipun sesami. Ical ngelih, ical keselipun pribadi. Ingkang dipun engeti namung kesel lan prihatinipun sesami. Luh ingkang medal saking manah kula puniko dede luhipun tangis pamrih, nanging luh peresanipun manah suwung pamrih. Luh ingkang mijil saking sucining batos lan raos. Ingkang tuwuh saking sucining bakti marang kersaning Gusti. Welas, welas Gustining jagad. Waras-waras saking kersaning Allah.”[1]

There are more inner tears, remembering that many people are in distress and misery; remembering that many people who are in sickness, and hunger; there are so many of them. In this way, all fatigue disappears. By thinking of, looking at and concentrating on the misery of others, the weariness and pain of oneself penetrating into the sea of misery and sorrow of others will be lost. We will lose our hunger, physical fatigue, when all that is remembered are fatigue and concerns of others. The tears that come out of the mind are not tears of selflessness, but are tears of the empty heart (suwung), tears that come out of inner purity and feeling, which grow because of filial holiness because of God's will. Compassionate, as compassionate as the Lord of the Universe. Healed, healed because of God's will. 
Such situation experienced by RMP Sosrokartono was also experienced by HOS Tjokroaminoto which was later presented at the 1916 Sarekat Islam National Congress in Bandung:

"It is not natural to see Indonesia as a cash cow because of milk (it produced). It is inappropriate to regard this country as a place where people come with the intention of taking the bounty, and at this time it can no longer be held accountable that indigenous people do not have the right to participate in political matters, which concern their own destiny, it can no longer be accepted that someone passes laws and regulations for us, rules our lives without our participation. " [11]

The same situation became the awareness of Soekarno as the student of HOS Tjokroaminoto and RMP Sosrokartono. Soekarno traveled to South Bandung around the 1920s and met Kang Aen or Marhaen. Marhaen was a poor farmer who was constructed by structural oppression in the Dutch colonial era. In seeing the oppressed reality, Soekarno brought up his phenomenal idea of Marhaenism.

When referring back to the meaning of Al-Ashr, it is clear that the surah carries out three important aspects (pious deeds, having a testament about the truth and patience), which in space and time, can only be done properly when all three are also at the same time in the void of any interest. The only existing interest and intention must be connected to reality in the name of Allah. The interest and intention of love should be without reservation because of Allah, and the love (mahabbah) always and only directed to Allah, Mahabbatullah. That is true faith.

\section{Results and Discussion}

\subsection{Past Era, Existing Era, and Future Era}

We can also trace the meaning of number 4 from the current contextual reality, where it is said that our industrial revolution is entering phase 4.0 as the millennial algorithm phase. There is nothing in the logic of 4.0 era that related to the present and future reality with regard to matters of moral deeds, goodness for many people, and eschatology of past activities.

The discussion about "era" in many traditions of any civilization always hinges on "the present" in which we exist, which cannot be separated from our past as well as our future. The big problem in the current dominant civilization era is that the reality of the past is no longer important, because the past is only a part of history that has been abandoned, has no regard for lessons learnt (ibrah), except for those that are part of the shaping of the present with the power of linear science and technology, that can be constructed in the future. The exploration of existing future studies, both in the context of futurology and foresight, has the same pattern, not concerned with the historical past, but with regard to the present and present science-technology, mentality, desire, planning, happiness, and anything else to be projected into the future.

We never seem to have thought further and deeper into the concept of futurology and foresight. In fact, as we know, futurology in the Western tradition and which is currently become the dominant idea of civilization has imperialistic connotations, capitalistic, and technocratic terms based on speed, technology, and "fusion of man and machine". It is even ideologically oriented "with a specific and political worldview". Another concept, foresight, concerns: "implies action in present, in light of anticipated future states of 
affairs", where the product is the main orientation, for the sake of "winning over others" through planning strategies and all other derivative forms that are strengthened in the realm of institutions, business and economy. The ultimate goal is a single meaning, namely: "one worldstate, one world-pax, with one money, one police, one speech and one brotherhood", while multiple possibilities may not be present [12].

I myself have written about the future of the country, which has a tight relationship with the past and the present, and can even be loaded with values that are contrary to the existing values of futurology and foresight [13]. Rationally speaking, it is noted that in the global geo-political and economic discussion, the year 2024 will achieve the peak of a crowded demographic, where statistically the number of humankind will reach 8 billion or more. This demographic calculation is based on the prediction that the number of people on earth since 1975 has increased by 1 billion every 12 years. In 2024, it is possible that the carrying capacity of the earth will become more vulnerable, the environment will be more damaged, food and energy will become more insufficient, horizontal conflicts between countries and civilizations will increase.

Domestically (Indonesia), in the years leading up to 2024, will experience increasingly dynamic political nodes, the culmination of which is simultaneous elections in all regions, starting with elections for mayors, regents, governors, presidents, city/regency DPRD, provincial, national, and DPD. In these years, it can be predicted that the political escalation will increase until 2024 unless there are significant changes, especially in state policy. The national economy ahead of 2024 will also not improve, starting with global climate change which has a profound impact on the domestic weather structure. This means that the possibility of crop failure, drought, poverty and many aspects of the economy are severely affected. On the other hand, the country's development priorities are still being sucked in by development peripherals such as technically with the issue of the 4.0 industrial revolution, the increasing middle class who is unproductive except for a consumptive mentality, as well as being very materialistic-pragmatic. Is the world really only portrayed in such limited material space?

I read it differently with the same point, the year 2024. The span of the mass is also clad in the uniqueness of the number 24 and the mystery of the Prophet's hadith regarding the 100 years of important changes in every niche of civilization, thus emphasizing the importance of 2024 for Indonesia's journey. For me, 100 years of strength, in this book, is a form of a typical Islamic institutional $\mathrm{drift}^{6}$ that has been written in the Book of Reality Lauhul Mahfudz, and not only constructed by an evolutive reality. The 100 years point from 624 Battle of Badr to reach Fathul Mecca 629, advances every hundred years, and can also be traced back every hundred years.

The journey of 2024 will reach the strength of its civilization when religious culture is used as the beginning of the change to a better divine state or hijrah, not politics and economics as the dominant idea, wherever the idea of changing a country is carried out towards its prosperity. Politics and economics are the logical consequences of the ideological design of culture, namely the constructive design of hijrah shura (antithesis of democracy in politics) and sharing economy hijrah (antithesis of liberal economics). The three of them, the Hijrah of Religious Culture, the Hijrah of Shura, and the Hijrah of the Sharing Economy, can take place when there is consolidation of the people or ummat

\footnotetext{
6 The long institutional change movement of a state as a result of reaction to the decisive historical momentum (see pages 13-14 in Mulawarman [13]). Detailed descriptions can be found in Acemoglu, D., and JA Robinson. 2014. Why States Fail: The Origin of Power, Prosperity and Poverty. Translation, Publisher Elex Media Komputindo. Jakarta.
} 
throughout the range of the hijrah agenda. Thus, strategic, tactical to practical designs can be projected precisely according to the spirit of Hijrah.

The concept of the future in the (post) modern era has clearly abandoned the historical past for the sake of certain ideological rationales and materialism, and is trapped in the logic of Eurocentrism [14]. It becomes natural that the concept of "era" which has become a present-day reality in which we are in leads to such a material orientation as I was worried and confused in the initial paragraph of this paper; until, because of the fear of being trapped in materiality, Rumi asked the following:

Look at yourself for a moment and ask who carved you.

Where did you come from, from what place, who carved you?

When viewed normatively, the happiness that humans seek is usually called ukhrawi / afterlife happiness (as-sa'adat ukhrawiyyah), which can be achieved through controlling the present worldly-oriented desires, innate desires, and selfishness, all the while leading to the intention of "not only" the world in the future but beyond that in the future post world (hereafter). Why so? Because it is the center of religious teachings, the prophets and apostles as well as all holy books are written either through sharia praxis (figh) or holy wisdom (tassawuf) [15]. In order for happiness to be achieved, it is necessary to balance the means of humanity (wasilah) with important gradations of spiritual/spiritual virtue (alfadha'il an-nafsiyyah) as the center, moving towards physical excellence (al-fadha'il aljismiyyah), external virtues. (al-fadha'il al-kharijiyyah), and ends with the importance of divine guidance (al-fadha'il at-tawfiqiyyah) [15]. The end goal is what is called: Wisdom, according to the hadith of the Prophet Muhammad PBUH: "Seeking wisdom is obligatory for you and that goodness is contained in wisdom", which is the basis of Philosophy (Wisdom) ${ }^{7}$ in Islam itself [10], which is of course very different from Western Philosophy. We name this as achieving The Essence of Truth (al-Haqq) as well as Rationality in the Purity of the Soul.

\subsection{Beyond "the Era"}

The concept of the era (past, present, future) seems to me and should not only be worldly in nature, but may indeed be oriented beyond the era itself. The disturbance of world-oriented (secular) knowledge gave birth to ideas and pragmatism over mechanical reality, in which space and time are filled by concrete realities only, whereas Ruhiyyah and Holy/Holy Reality which are undefined by reason and physically cannot exist in historical time space:

"Reality is reduced to a process, time to mere quantity, and history to a process without transcendent entelechia. Time and not eternity, is the source of all things. From the time there arose the doctrine of historicism, it turned out that any explanation of the historical development of a phenomenon would not be able to explain the "why" and "what caused it". This doctrine knows no permanent and eternal. As a result, history lost touch with the Holy One ... Emotivism value theory, introduced by Russell (1872-1970), Ayer (born 1901), Schlick (1882-1936), and Hume (1711-1776) as well as many Anglo-Saxon morals and other Russians

7 "Alaika bi al-hikmah fa inna al-khair fi al-hikmah." 
have reduced morals to gross emotional outbursts, at least, fad and chaotic moods... values are born only through human choice, making values highly relative and impermanent. As a result, insight into the Holy One disappeared from the world of values. The so-called atheistic religions of the twentieth century, such as Communism, Logical Positivism, Psychoanalysis, and Existentialism, to name just a few, have discarded the spiritual content of religion and emphasized only the worldly and the dirty ... resulting in compartmentalism and fragmentalism in human life. Modern humans suffer from feelings of alienation and anomy ... "[16]

The idea of Islam itself actually goes beyond such historical secular ideas. The Islamic religious tradition, as I explained in previous paragraph, may be more appropriate as a reference. Religion is a part that should construct life (because of faith, as a form of belief of truth). An important reference in Islam regarding the concept of "era" can be seen from an eschatological concept, as illuminated by one of the important verses refers to the Qur'an, Surah Fushilat (41) verse 53:

We will show them the signs of Our (power) in all regions of the earth and in themselves, until it is clear to them that the Qur'an is true. Is it not enough that your Lord is a witness to all things?

The Qur'an clearly shows that present actions, which will later become our historical past, will have an impact on the future with all the consequences of four important human realities, namely moral actions ( $f$ i anfusihim) from the past displayed in the real world ( $f i l$ afaq) which will later be broadcast in post space (la makan) and post time (la zaman). Not only that, the number 4 turns out to be a true reality in this verse (fi anfusihim, fi l-afa, la makan, la zaman) [17] as well as 4 realities that arise from the representation of the mathematical nature of the number $9(1+5+3)$. Any number if added to the number 9 will still bring up the number itself (4).

The verse also provides an important symbol, that the concept of era does not stop at historical space-time only, it does not stop at past, present, and future time spaces. Era in historical space and time is not only centered on logical consequences, but moves even further towards the peak of reality itself, namely Reality, Allah SWT. Allah SWT has more power than just such historical eras. The concept of era is no longer important when Allah has power over "Be" (Kun Fayakun):

Allah is the Creator of the heavens and the earth, and if He wills (creates) something, then (it is sufficient) He only tells him: "Be!" So be it. (Qur'an, Surah Al Baqarah 2 verse 117)

Verily, We say to something when We will, We only say to him: "Be!", Then be it. (Qur'an Surah An-Nahl 16 verse 40) $^{8}$

\footnotetext{
8 The words Kun Fayakun is expressed in the Qur'an as many as 7 times. Besides the two verses, kun fayakun can also be found in Qur'an Surah Ali Imron 3 verse 47 and 59, Qur'an Surah Yasin 36 verse 82, Qur'an Surah Al-Mu'min 40 verse 68, Qur'an Surah Maryam 19 verse 35, dan Qur'an Surah Al-An'am 6 verse 73.
} 
The occurrences of existence are no longer based on the congruence of our past actions which have an impact on the present and the future. Kun fayakun's action does not want the existence of reality to exist and be created to exist, whether existing at that time or constructed into something new in space and time, but beyond it. Belief in kun fayakun is not about playing games, Even Allah SWT emphasize in various events to show the Prophet Muhammad PBUH through historical, existing, present, even future realities, which in the three realities of the era, events without any pre-conditions or construction as understood as a technological event as well as an individual to sociological endeavor, but it just happens, based on His orders. Ibn Arabi [18] expressed such incidents with what he called the concept of Tripilicity, which later formed Bipolar Triplicity (al-jani-bain), tripilicity which has two poles.

Triplicity itself is the basic form of a united creative process. "Bipolar Triplicity", is a representation of two basic poles of the Allah-Cosmos polarity, the third factor of the relationship of two things. These three elements are united in the Unity of Being, with 2 (two) and 4 (four) important terms based on the first polarity, namely the Reality of Allah, and the second polar, namely the Cosmos in which humans are located. Between the first polarity, which always has two terms, namely a Divine term as well as a Cosmic (world) term, and when the end term moves dynamically in time space, a contextual term emerges that becomes the meeting point of the two ends of terms, as a middle way for the two polarity to unite. This is called the destiny of polarity which unites both in the consciousness of free space and time. Fate is the main keyword, where space and time move dynamically with Kun Fayakun's affirmation; "Be! So be it":

"The principle of triplicity includes the existence of ideas achieved by logical evidence. Thus, a proof reached by a syllogism consists of three parts in a particular way, which is sure to produce a result. First of all, the person shows two premises, in which each of them has two terms, so that there are four terms. However, one of the terms is in both premises, to connect the two together, so that there are three parts because of the repetition of one of the terms in the two premises. The evidence becomes available when this particular arrangement appears, which is the bonding of two premises together by repeating one term, resulting in a triplicity. The special condition that accompanies it is that the major term must be more general than the middle term, or at least the same if the result is true, and otherwise it will not be true. This type arises in beings, such as things when actions are solely given to the servant without reference to Allah, or when events become manifest, which we are talking about here, are solely from Allah, whereas Reality ascribes them to the object in which the word "Be!" addressed."[18]

Representation of Bipolar Triplicity when discussing the wisdom of the singularity can be found in the sermon of the Prophet Muhammad PBUH, as he once stated: "Three things that are loved to me in this world from your world; women, fragrances, and prayers":

"He ordained the wisdom of the singularity to Muhammad PBUH because he was a very perfect creation of the human kind, where the reason for the whole matter of 
creation begins and ends with him. He was a Prophet when Prophet Adam was still between water and clay and through his elemental actions, he was the Seal of all the Prophets (khatam an-Nabiyyin), the first of the three who remained because all that was singular came from him. He is the clearest proof to his Lord, who has been given the totality of the divine words, in which they are named by Prophet Adam, so that he becomes the closest indicator of his triplicity, he makes himself proof of himself. Then because Muhammad's PBUH reality is characterized by a primal singularity (al-fardhiyyah al-ula) and his creation through tripilicity (musallas), he speaks of love which is the origin of all existing existence: Three things that are loved to me in this world from your world; because triplicity (taslis) is inherent in Muhammad's (self). Then he mentioned women and their fragrances, and added that he found pleasure in prayer." [18]

Figure 1. "Era" Bipolar Tripilisity 2-4 Term.

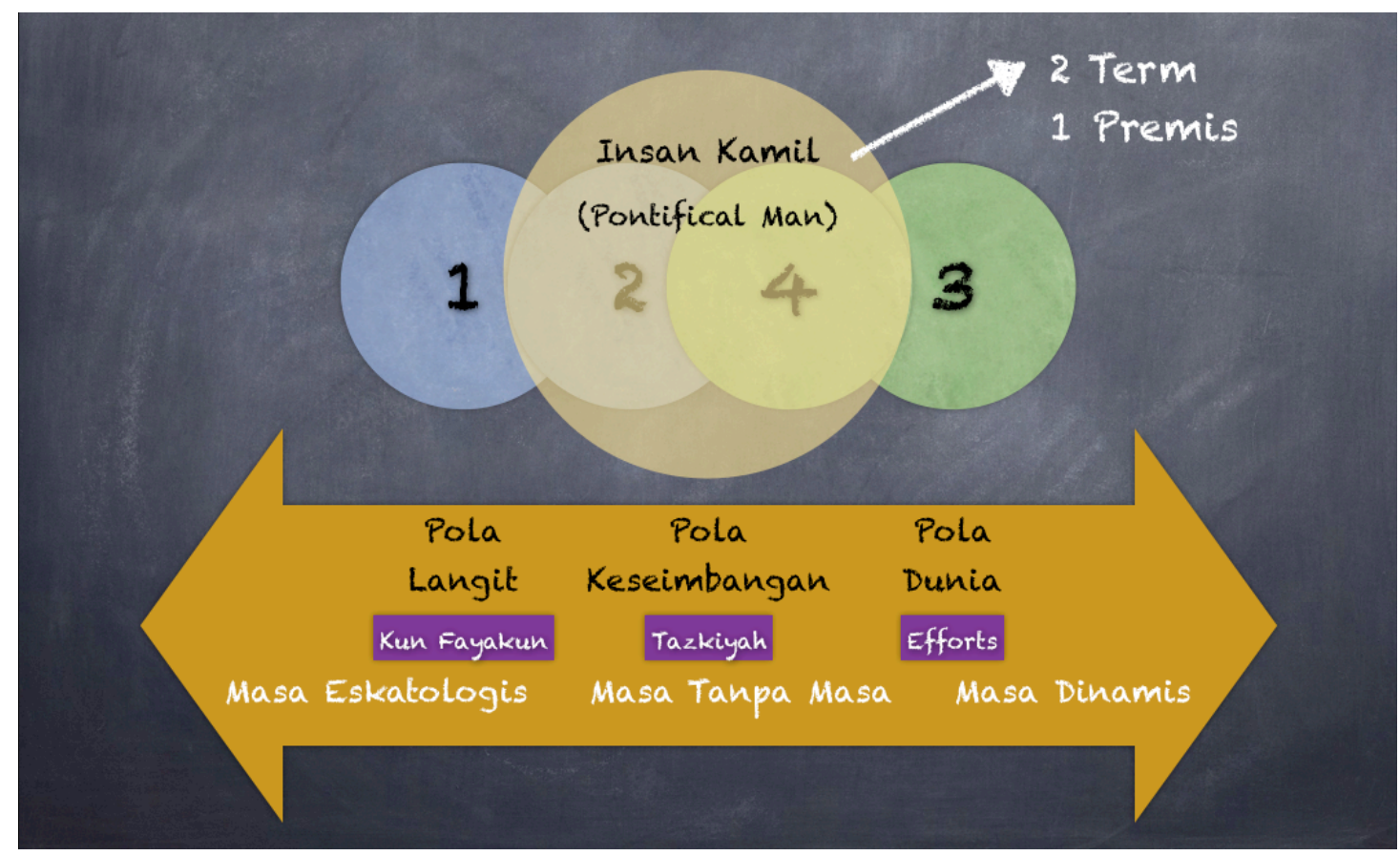

Source: Modified from Arabi [18]

For Ibn Arabi, the representation of humanity is in the presence of male and female bipolarity, a representation of masculinity and femininity where both are part of the destiny to unite holiness to form creation in space and time with the presence of Allah in every process of creation without pause, as well as the process of creating creatures. A new life will be created because of the male attraction to love, longing, tenderness, beauty, happiness, including the downfall, wildness, and all the representations, that Allah SWT presents in a woman when she unites with a man:

"When a man gazes at the Reality (shahada) in a woman, he sees Him in a passive aspect (munfa'al), whereas when he looks at Himself, as the being that woman is manifested from, he sees Him as an aspect. active (fa'il). but when he sees Him to himself, without some respect to what comes from him, he sees Him as passive to Himself directly. However, his fixation on Reality in women is more complete and 
perfect because in this way he looks at Allah in an active and passive way, whereas looking at Reality only in himself, he sees it in an especially passive way.[18]

It could be that Ibn Arabi's explanation can be interpreted too masculine, because the representation of women is in the time space subordinated by men. It is interesting to view the interpretation of women, fragrances, and prayers, not in a physical context, but rather enters the representation of meaning in human nature, the true nature of man lies in both the masculine and the feminine nature, whoever he is, because the unity of the masculinefeminine nature is jamal (beautiful, feminine) and jalal (strong, tough, masculine) to their unity, namely true kamal, real human being, Insan Kamil.

I try to illustrate Ibn Arabi's explanation by modifying according to the idea of "era" (see figure 1) regarding the existence of ideas that are present in the space of the deepest human consciousness, showing a dynamic movement from the circle of ideas term 1 to the circle of ideas term 2 and 3 to the circle of ideas: term 4 . The circle of ideas in term 1 can be said to be a circle of ideas that has a celestial pattern, where all references are in Allah. The circle of ideas in term 4 is the circle of ideas that has a world pattern. Between the celestial and world patterns there is a circle of ideas of terms 2 and 4, each of which becomes a meeting point between circles 1 and 3. The circle of ideas in terms 2 and 4 is the meeting point of two circle of ideas whose patterns are diametrical but meet to form a point of balance.

Each circle forms a dynamic pattern depending on the strength of the belief that exists in each individual, if in the world pattern, the power of existence is fought as a form of rational-material efforts continuously. The dynamics of the efforts of efforts may move at the midpoint when humans have Divine consciousness, where the celestial point is the diametral point. The point of the celestial pattern is a representation of the power of the sky, where strength and power exist in only one, namely Allah SWT, including in the Kun Fayakun pattern: "Be, then be!". When the Divine consciousness starts to dynamically move its rationality as well as its inner consciousness, then human desire and efforts are not necessarily important without external power:

"So Reality shows that the event into existence comes from something itself and not from Reality, which is the origin of the Commandment. So, He spoke of Himself... Here, He attributed the occurrence of something itself to Allah's command, and Allah must have spoken the truth. This is understood in the Commandment, as when someone is afraid and obeys the commandments to endure, the person or slave abides obediently. Regarding the survival of the slave, the command to obey him belongs only to the master (master), what remains is the act of the slave, not the master's. So, the existence of the existence is based on a tripliciptas, or more based on a bipolar triplicity, one from Reality, and the other from humans. " [18]

The balance of the pattern between efforts and the power of heaven forms the principle of purification (tazkiyah) continuously without pause and with that the power of humanity becomes a timeless force, free of space and time on the one hand, on the other hand, at the same time very bound by time and space. Humans who are ready to balance the heavens 
and the earth are called humans who have reached perfection, Insan Kamil, the holy man (pontifical man) ${ }^{9}$.

\subsection{I'tidal to Surpass "Era" Without era}

The "era", both historically, beyond it, to the divine provisions never seem to be separated from holiness, for Islam, action is never separated from sacred moral behavior in accordance with the character of the Qur'an. In essence, holiness is where the span of the past, present and future is no longer important, even lost, the era without any era. But on the other hand, holiness must be historical for the task of the public in the name of love for Allah SWT which is part of the deepest consciousness of every human being and human relations where the past, present and future move historically in time and space. In fact, furthermore, are people happy who always purify their souls (tazkiyah) without pause in the historical space of time, even surpassing them: "Truly happy people who purify their souls." (Surah Asy Shams 91 verse 9)

Purification of the soul is like water that flows to heal the reality of things with their coolness and thereby reducing all increased states and increasing all diminishing states, achieving i'tidal (equilibrium). I'tidal to balance everything from the power of thinking and the patience of submission, because only to Him all matters are returned and all offerings to Him are full of piety (Qur'an Surah 11 verse 123) [18]. That is how Allah SWT shows the seriousness of humanity in infinite patience and the purity of the soul is the most effective medicine to face and live reality with full happiness, because that is the meaning of true patience.

I'tidal is the practice of real prayer, actual practice where humans can reach true holiness. That is how Allah teaches infinite patience to the Prophet Ayyub AS. on the way to obey His Power, through the patience: from a very rich man to a poor man, from a healthy person to a man afflicted with constant illness. Only by Allah's order at his request for a cure because of his wife's disobedient character, until his later recovery, did not whip his patience with violence. The purity of the soul is full of $i^{\prime} t i d a l$, everything is full of patience and love, for everything is brought to his life with balance.

Hence, in fact, for civilization survivors, survivors of the universe, i'tidal behavior is only because of sincerity that is the practice of holiness in facing the past, present and future until the era transcends era to reach era without era. Islam as a religion has a distinctive character with what is known as Din [19]. Din is not just a concept but is not just a concept but is something that is active in translating reality and living in human experience. For Islam, i'tidal action according to the character of the Qur'an is an act of publicity in all the lines of history where we are, without it our actions are useless foam $(a d z-d z a b a d)$ :

"Allah has sent water (rain) from the sky, so the water flows in the valleys according to its size, so the current carries floating foam. And from what (metal) they melt in the fire to make jewelry or tools, there is (also) foam like the foam of the stream. This is how Allah parables (for) the true and the false. As for the froth, it will disappear as something that is worthless; anyone who benefits humans, then he remains on earth. This is how God makes parables." (Qur'an Surah Ar-Rad 13 verse 17)

\footnotetext{
${ }^{9}$ The term Pontifical Man or holy man refers to the term used by Syed Hossein Nasr [22]
} 
It became natural why ushwah Rasulullah, Muhammad PBUH from the time of prophecy until the end of his life, three important words were spoken by him: Ummati, Ummati, Ummati (my people, my people, my people). Hopefully we are, as he preached: "The best human being is the most beneficial for other human beings" (Narrated by Thabrani and Daruquthni). The act of Rasulullah PBUH who always served the ummah throughout his prophethood was called a human with the highest degree, a human who had peak understanding (Mufahhamun). Mufahhamun is a human being who has the ability and high angelic nature, as well as being able to control worldly characteristics, and thus gets the task of building structures of civilization according to the call of heaven (da'iyah haqqaniyyah) as the will of Allah SWT [20].

\section{Conclusion}

In this final note of surpassing era, I hope that we are part of history in the entire trajectory of civilization that continues tirelessly (may Allah SWT give us all the strength) to try our best to follow this prophetic mufahhamun practice, towards human perfection, human authenticity. That is what HOS Tjokroaminoto calls a real human, Insan Kamil:

"... in order to become stronger attached to the religion of Allah, the ultimate religion (Islam), and with that we carry out it fully and as widely as possible, to get the salvation of the world and the hereafter, and then to save the Land of Spilled Blood, our nation and our people. No matter what."[21]

Only to Allah SWT will love be poured out, and with His love too, may we all be able to bring the wellbeing (maslahah) of the Ummah who always radiates His light. Hopefully, longing for You, O Allah, is longing across space and time, era without era, passed with endless submission, sincerity, that is true emptiness towards the unity of holiness, as RMP Sosrokartono wrote: "Trimah mawi pasrah. Suwung pamrih, tebih ajrih; Langgeng, tan ana susah, tan ana seneng. Anteng mantheng, sugeng jeneng."

If you are still trapped

In materialization of space and time

Still tempted by

The idols of modernity, money and power.

Then, you never will

Can follow makrifat behavior

Of the Prophet

Hurry up and throw them all away

All through your $d h i k r$

Across and beyond space and time.

\section{References}

[1] Sosrokartono R. Serat Saking Tanjung Pura (Langkat). Istana Sultan Langkat DarUl-Amani, 26 Oktober. In: Suxmantojo, editor. Kumpul. Serat-serat Drs. RMP Sosrokartono, Surabaya: 1931.

[2] Shihab Q. Tafsir Al Misbah: Pesan, Kesan dan Keserasian Al-Quran. Volume 15. 
Jakarta: Penerbit Lentera-Hati; 2000.

[3] Schimmel A. The Mystery of Numbers. New York: Oxford University Press; 1993.

[4] Mulawarman AD. Akuntansi Pertanian: A Prophetic Legacy. Jakaera: Yayasan Rumah Peneleh; 2019.

[5] Howell RW. Mathematicians and Their Gods: Interactions Between Mathematics and Religious Beliefs. Hist Math 2018;Book Revie.

[6] Reid C. Hilbert. Springer-Verlag Berlin Heidelberg GmbH; 1970.

[7] Strong E. Newton and God. J Hist Ideas 1952;13:147-67.

[8] Kaku M. Parallel Worlds. Doubleday; 2005.

[9] Nasr SH. Science and Civilization in Islam. Chicago: ABC International Group; 2001. doi:10.1007/s13398-014-0173-7.2.

[10] Nasr S, Leaman O. Ensiklopedi Tematis Filsafat Islam. First. 2003.

[11] Mulawarman AD. Jang Oetama: Jejak dan Perjuangan HOS Tjokroaminoto. Yogyakarta: Galang Press; 2015.

[12] Sardar Z. The Namesake: Futures; futures studies; futurology; futuristic; foresightWhat's in a name? Futures 2010;42:177-84. doi:doi:10.1016/j.futures.2009.11.001.

[13] Mulawarman AD. 2024: Hijrah untuk Negeri (Indonesia dalam Ayunan Peradaban). Jakarta: Yayasan Rumah Peneleh; 2017.

[14] Sardar Z. Masa Depan Islam. Bandung: Penerbit Pustaka; 1987.

[15] Quasem M. Etika Al-Ghazali. Bandung: Terjemahan. Penerbit Pustaka; 1988.

[16] Qadir C. Filsafat dan Ilmu Pengetahuan dalam Islam. Terjemahan. Pustaka Obor Indonesia; 2002.

[17] Gunther S, Lawson T. Road to Paradise: Eschatology and Concept of Hereafter in Islam. Volume 1,. Leiden - Boston.: BRILL; 2017.

[18] Arabi I. Fusus Al Hikam: Mutiara Hikmah 27 Nabi. Translated. Yogyakarta: Penerbit Islamika; 2004.

[19] Al-Attas S. Islam and the Philosophy of Science. Kuala Lumpur.: International Institute of Islamic Thought and Civilization; 1989.

[20] Al-Dihlawi S. Hujjah Allah al-Balaghah: Argumen Puncak Allah, Kearifan dan Dimensi Batin Syariat. Jakarta: Penerbit Serambi; 2005.

[21] Tjokroaminoto HOS. Memeriksai 'Alam Kebenaran. Jakarta: Yayasan Rumah Peneleh; 2019.

[22] Nasr S. Knowledge and the Sacred. Sunny Press; 1989. 